\title{
Comparison the Effect of Consumer Behavior on Visiting Intention to the Shopping Centre During COVID-19
}

\author{
(Case Study in Bandung, Solo and Kupang)
}

\author{
Ronald P. C. Fanggidae ${ }^{1, *}$ Antonio E. L. Nyoko ${ }^{1}$ Merlyn Kurniawati ${ }^{1}$ Klaasvakumok \\ J. Kamuri ${ }^{1}$
}

\author{
${ }^{1}$ Department of Management, Nusa Cendana University, Kupang, Indonesia \\ *Corresponding author. Email: ronaldfanggidae@staf.undana.ac.id
}

\begin{abstract}
For this study, the focus is on how cultural, social, personal and psychological factors influence the intention to visit a shopping center (mall) in Bandung, Solo, and Kupang in three cities. In Indonesia, there are three types of cities: large, medium, and tiny. The novelty of this research is to fill the gap in the limited research that examined the intention to visit a shopping center (mall) during Covid-19, particularly in contrast to other cities. This is a quantitative study, and the data collection methods include a questionnaire and direct observations. Customer Behavior and Visiting Intention are examined using Multiple Regression Analysis, which includes validity and reliability tests as well as the assumption of the classic assumption. Findings from the Covid-19 pandemic in Bandung, Solo, and Kupang show that Personal Factors have a positive and significant effect on Visiting Intention to the shopping centers, while Cultural and Social Factors in Solo City, and Psychological Factors in Kupang City, have a positive and significant effect on Visiting Intention to the shopping centers during the Covid-19 pandemic. Businesses and marketers can benefit from this study by developing the right marketing tactics based on consumer behavior in order to attract customers to their establishments.
\end{abstract}

Keywords: Consumer behavior, Cultural factors, Personal factors, Psychological factors, Social factors, Visit intention.

\section{INTRODUCTION}

People in the cities in Indonesia are consumptive and increasing in recent years and the level of demand for consumer goods has increased quite high. This can be seen from the growing of shopping places - small, medium and large scale- in the central to the rural of the city. Consumption trends that are classified as consumptive increases the interest of providers of goods and services, especially in the fulfilment of basic needs that support consumption. This reason makes producers and providers of goods and services compete in increasing their supply and trying to attract the consumer's attention, so that the consumptive people are interested and decide to buy. To take this opportunity, marketers must be able to understand and study the consumer behavior so that they will be able to understand the characteristics of real consumers.
Consumer behavior is an image that shows an explanation of what consumers need both in the short and long term. This condition will also be a strong reason why consumers decide to make a purchase as well as what factors drive it strongly to influence their decision to make a purchase. According to [1], consumer behavior is the direct action involved in acquiring, consuming, and depleting products and services, including the processes that precede and follow these actions. [2] revealed that consumer behavior can be influenced by several factors, including Cultural Factors, Social Factors, Personal Factors and Psychological Factors. These factors affect the interest in shopping or visiting intention to the shopping centres.

However, in recent months Indonesia has been affected by the coronavirus pandemic or Covid-19. The enactment of Large-Scale Social Restrictions (PSBB) by 
the government was imposed in an effort to limit the spreading of the deadly virus. People stay at home until the uncertain time by the government rules. Regardless, the consumption trends of the consumptive consumers were suddenly drastically reduced because of these restrictions so that the producers experience a very abnormal limitations to develop their business.

Looking at the situation, it can be seen that the marketing theory based on the marketing mix by [3], is now undergoing a shifting. Consumers are more concerned with the fulfilment of basic needs that can support to survive. The situation has transformed people's perceptions into a new psychological level in determining its decision to make purchases of basic goods. Under normal circumstances, products, prices and places can have a direct effect on purchasing decisions, but in an emergency Covid-19, it will lead to other results. Consumer behavior also change in the situation of Covid19 pandemic.

Consumer behavior in each city is different depending on customer characteristics, consumer behavior and facilities provided by shopping malls. This difference will cause differences in the marketing strategy to attract customers to visit shopping centres. Therefore, marketers need to know their consumer behavior in order to determine the appropriate strategy in attracting the shopping interest and visiting intention of their customers.

Based on the description above, further research is needed to study the effect of consumer behavior on the visiting intention to shopping centres during Covid-19 in three different cities Bandung, Solo and Kupang. This research was conducted because of the limited literature that discusses the effect of consumer behavior on the visiting intention to shopping centres and there has been no empirical research that discusses the comparison of consumer behavior to the visiting intention to shopping centres during the Covid-19 pandemic. The reason for choosing these three cities is to represent cities in Indonesia: Bandung (big city), Solo (medium city) and Kupang (small city).

The purpose of this study was to find out the comparison of consumer behavior in visiting shopping centres in three cities (Bandung, Solo and Kupang) during the Covid-19 pandemic. This research contributes to the businessmen and marketer to formulate the appropriate marketing strategies regarding to attract the customers visiting intention based on the consumer behavior.

\section{LITERATURE REVIEW}

\subsection{Consumer Behavior}

When it comes to consumer behavior, [4] states that it's the study of how people and groups make decisions about what they want and how they get it. When it comes to purchasing, consuming, and using products and services - including all of the procedures that precede or follow these actions - consumer behavior is defined by [1], Decision-making units and processes involved in obtaining, using, and determining goods, services, and ideas are the focus of consumer behavior, according to [5]. Consumption, as described by [6] is the act of getting, consuming, and spending goods and services, as well as the processes that precede and follow these actions. Individuals who are directly active in purchasing and using goods and services, as well as the decision-making process that goes into preparing and determining these actions, are considered consumers [7].

Ref [2] revealed that consumer behavior can be influenced by several factors, including;

1) Cultural Factors; Cultural factors include: (a) Culture is the most basic determining factor of one's desires and behavior. Marketers are always trying to recognize cultural shifts to find a new product that is desired; (b) Sub-Culture is the identification and socialization typical for the behavior of its members. There can be distinguished four types of sub-cultures, namely: national groups, religious groups, racial groups and geographical areas; and (c) Social Class, is a relatively similar group and survives in a society, organized in a sequence of levels, and members at every level have the same values, interests and behaviors.

2) Social Factors; Social factors that include: (a) Groups, attitude and behavior of individual who is influenced by many small groups. Groups that directly affect to individual are called membership groups. Reference groups, appearing as direct or indirect references to form a person's attitudes and behavior. The aspirational group who are not include members but has the desire to participate/follow. Groups usually have opinion leader, the one who in reference groups, because of the skills, knowledge, personality, or other special characteristics have an influence on other members; (b) Family Members, family members greatly influence the behavior of buyers. Family is still the most important consumer purchasing organization in society; (c) Role and Status, Each role carries a status that reflects the general appreciation given by society. Roles and statuses are not constant variables. Many marketing and sales professionals make a misjudgements related to the role and status of potential customers

3) Personal Factors; Personal factors include: (a) Age and Stage of Life Cycle, the types of goods and services purchased by consumers change with age. Marketers often define their target market based on cycles, and develop suitable products and marketing plans; (b) Work/Job, work affects the goods and 
services that a person/consumer buys. When it comes to a company's marketing strategy, it's important to look for employment groups that are more interested in products and services than the general population; (c) Economic Situation, marketers need to keep an eye out for trends in personal income, savings, and interest rates. During a recession, they can design and reposition their products; (d) Lifestyle, dimensions of selforientation make three kinds of buying approaches available to buyers, namely: principle-oriented; status-oriented; and action-oriented; and (e) Personality and Self-Consciousness; and (f) Behavioral Economics, which focuses on how consumers make decisions. Analysis of consumer behavior toward different products and brands might benefit from personality.

4) Psychological Factors; Psychological factors, including; (a) Motivation, is a needs that encourages a person to seek satisfaction; (b) Perception, is every action of a motivated person who will be influenced by his perception of a particular situation. Perception is the process of selecting, organizing, and interpreting information inputs; (c) Learning, includes changes in a person's behavior arising from experience. Learning theorists believe that learning is generated through a combination of drive, stimulation, instruction to act, response, and reinforcement; and(d) Beliefs and Attitudes, beliefs can form the image of products and brands, and consumers will act based on those images. Consumers often maintain easy-to-see beliefs about brands based on the origin of their countries.

\subsection{Visiting Intention}

According to [8], the theory of visiting intention is analogous to buying interest. Ref [4] states that interest in purchasing a product is sparked by the sight of the product, which then leads to the urge to test the product, and lastly the want to purchase the thing in order to own it. Visitor intent in this situation is a form of or interest in performing a certain way., while the definition of interest in behaving according to [9] is theoretically distinguished from attitude that is interpreted as a potential tendency to negate the reaction. So it can be explained that the attitude precedes behavior.

Overall, the theoretical framework of this research can be seen from figure 1 .
Consumer Behaviour

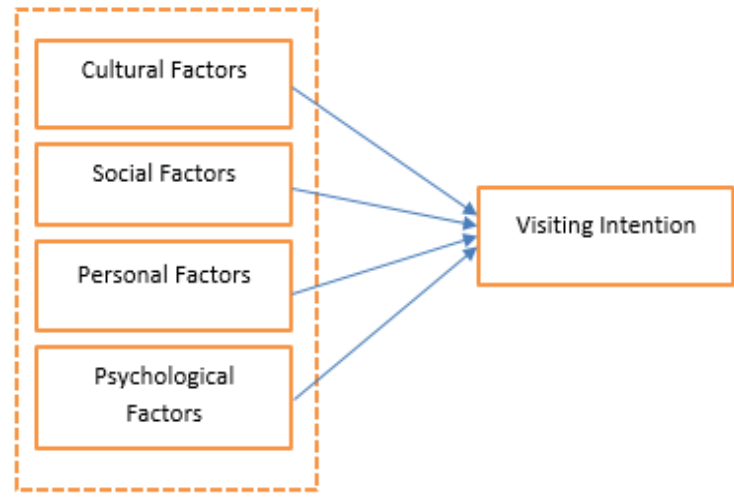

Figure 1 Theoretical framework

\section{METHOD}

This research uses quantitative method approaches. According to [10], quantitative research is a process of finding knowledge that uses data in the form of numbers as a tool to find information about what we know. Quantitative research methods in this study use comparative research. In this study, a comparison of the influence of Consumer Behavior on the Visiting Intention to shopping centre during the Covid-19 pandemic in three cities : Bandung, Solo and Kupang. According to [11], comparative research is essentially research to find similarities and differences about objects, people, work procedures, ideas, criticism of people or groups, to ideas or a work procedure. It can also be used to compare common views and changes in the views of people, groups or countries to cases, events or ideas.

In this study, the number of population is unknown, so the determination of sample sizes from the population according to Roscoe in [12] suggested the size of a decent sample in the study is 30 to 500. The samples taken from each city are 30 samples in Bandung City, 40 samples in Solo City and 30 samples in Kupang City, so the total is 80 samples. Sampling techniques in this study is Accidental Sampling. According to [13], Accidental Sampling is a technique of determining samples based on coincidence, i.e. consumers who coincidentally meet the researchers can be used as samples, if the respondents are suitable as a source of data.

Collecting data method are questionnaire and observation. Multiple Regression Analysis is used to analyse the influence of customer behavior to visiting intention, including validity test, reliability test and classic assumption. From the results of regression, a comparison of results in 3 cities was carried out and then an analysis of each indicators was carried out. 


\section{RESULTS \& DISCUSSION}

The research was conducted in three different cities: Bandung City representing a big city, Solo City representing a medium city and Kupang City representing a small city, and obtained data from 30 respondents in Bandung, 40 respondents in Solo and 30 respondents in Kupang with survey data and respondent characteristics as shown in figure 2,3,4 an tabel 1,2.

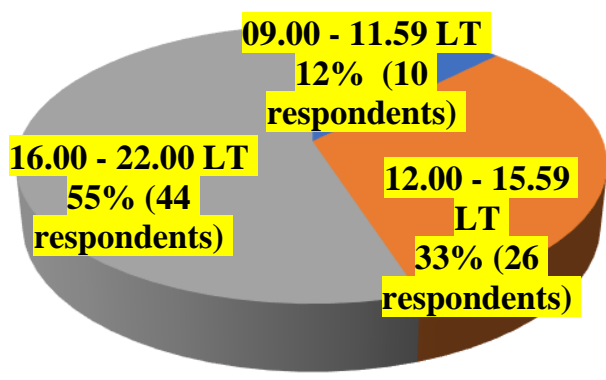

Figure 2 Number of respondents based on survey time

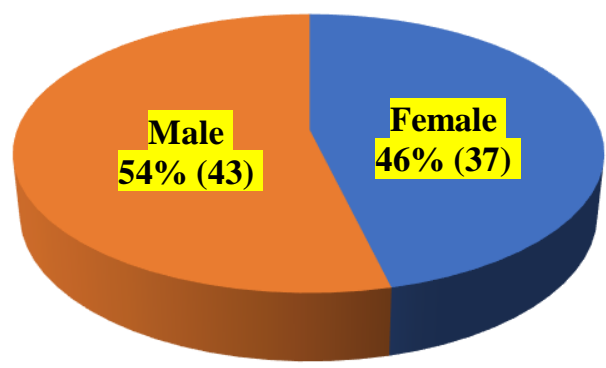

Figure 3 Number of respondents based on gender

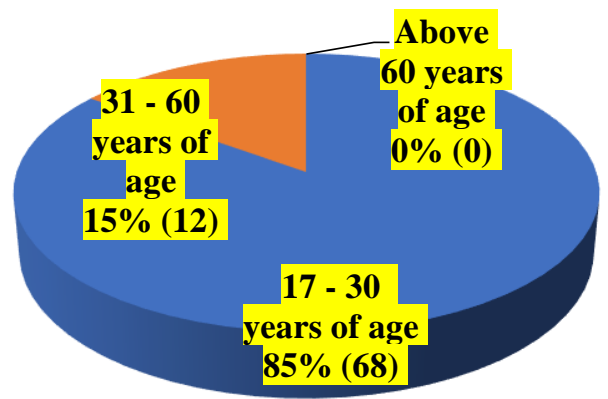

Figure 4 Number of respondents based on age
Table 1. Number of respondents based on job

\begin{tabular}{|l|c|c|}
\hline \multicolumn{1}{|c|}{ Jobs } & $\begin{array}{c}\text { Number } \\
\text { (people) }\end{array}$ & Percentage \\
\hline Government Officer/ & 2 & $2 \%$ \\
\hline Military / Policemen & 2 & $3 \%$ \\
\hline Private Employees & 15 & $19 \%$ \\
\hline Entrepreneurs & 12 & $15 \%$ \\
\hline Teacher / Academics & 1 & $1 \%$ \\
\hline Students & 47 & $59 \%$ \\
\hline Others & 1 & $1 \%$ \\
\hline
\end{tabular}

Table 2. Motivation to Shopping Centre

\begin{tabular}{|l|c|c|}
\hline \multicolumn{1}{|c|}{$\begin{array}{c}\text { Motivation to Shopping } \\
\text { Centre }\end{array}$} & $\begin{array}{c}\text { Number } \\
\text { (people) }\end{array}$ & Percentage \\
\hline Shopping & 34 & $26 \%$ \\
\hline Refreshing/Boring at home & 42 & $32 \%$ \\
\hline Invited by friends / dating & 16 & $12 \%$ \\
\hline Bring the families & 9 & $7 \%$ \\
\hline Meet up / reunion & 2 & $1 \%$ \\
\hline Hang out in café & 12 & $9 \%$ \\
\hline Eating at restaurant / food & 11 & $8 \%$ \\
\hline $\begin{array}{l}\text { Works / Meeting the client- } \\
\text { business partner-customer }\end{array}$ & 6 & $5 \%$ \\
\hline Others & 0 & $0 \%$ \\
\hline
\end{tabular}

From the data of survey time and the characteristics of respondents above, it can be seen that the survey has covered all time intervals range from open to close the shopping center. In terms of gender and age has been represented both men and women and all age ranges except the age above 60 years. Difficulty getting respondents over 60 because at that age is very risky to visit shopping centers during the Covid-19 pandemic. For the type of job, the largest number of respondents encountered were students and private employees. This makes sense because during the pandemic this group is more willing to take risks to go to public places. From the motivation to the shopping centers, most of respondents' answer was to refreshing (boring at home) and shopping.

\subsection{Validity and Reliability Test}

The purpose of this testing is to test the validity and reliability of the instrument using SPSS for Window software version 22, the following results as shown in Tabel 3 and 4: 
Table 3. Result of Validity Test

\begin{tabular}{|c|c|c|c|}
\hline Items & $\begin{array}{c}\text { Pearson } \\
\text { Correlation }\end{array}$ & r-table & Remarks \\
\hline X1.1 & 0.721 & 0.221 & Valid \\
\hline X1.2 & 0.607 & 0.221 & Valid \\
\hline X1.3 & 0.564 & 0.221 & Valid \\
\hline X1.4 & 0.645 & 0.221 & Valid \\
\hline X2.1 & 0.742 & 0.221 & Valid \\
\hline X2.2 & 0.518 & 0.221 & Valid \\
\hline X2.3 & 0.515 & 0.221 & Valid \\
\hline X2.4 & 0.531 & 0.221 & Valid \\
\hline X3.1 & 0.524 & 0.221 & Valid \\
\hline X3.2 & 0.545 & 0.221 & Valid \\
\hline X3.3 & 0.726 & 0.221 & Valid \\
\hline X3.4 & 0.749 & 0.221 & Valid \\
\hline X3.5 & 0.636 & 0.221 & Valid \\
\hline X4.1 & 0.377 & 0.221 & Valid \\
\hline X4.2 & 0.709 & 0.221 & Valid \\
\hline X4.3 & 0.641 & 0.221 & Valid \\
\hline X4.4 & 0.703 & 0.221 & Valid \\
\hline X4.5 & 0.703 & 0.221 & Valid \\
\hline X4.6 & 0.640 & 0.221 & Valid \\
\hline X4.7 & 0.598 & 0.221 & Valid \\
\hline X4.8 & 0.378 & 0.221 & Valid \\
\hline Y1 & 0.655 & 0.221 & Valid \\
\hline Y2 & 0.739 & 0.221 & Valid \\
\hline Y3 & 0.779 & 0.221 & Valid \\
\hline Y4 & 0.626 & 0.221 & Valid \\
\hline Y5 & 0.577 & 0.221 & Valid \\
\hline Y6 & 0.535 & 0.221 & Valid \\
\hline
\end{tabular}

Table 4. Result of Reliability Test

\begin{tabular}{|c|c|c|c|}
\hline Items & Cronbach Alpha & $\begin{array}{c}\text { Cut off } \\
\text { value }\end{array}$ & Remarks \\
\hline X1 & 0.721 & 0.6 & Reliable \\
\hline X2 & 0.607 & 0.6 & Reliable \\
\hline X3 & 0.564 & 0.6 & Reliable \\
\hline X4 & 0.645 & 0.6 & Reliable \\
\hline Y & 0.742 & 0.6 & Reliable \\
\hline
\end{tabular}

Source: Processed Primary Data by SPSS (2021)

From the results of validity test and reliability test, it was concluded that the instrument was declared as a valid and reliable measurement instrument.

\subsection{Classic Assumption Test}

The classical assumption test is a prerequisite of Multiple Regression Analysis in order to assess the parameters and coefficients of regression is unbiased. The classic assumption test are Normality Test, Multicollinearity Test and Heteroscedasticity Test. The results of the classic assumption test:

\subsubsection{Normality Test}

From figure 5, it shows that the data follows the diagonal line's orientation and exhibits a normal distribution pattern as it spreads around it. As a result, the regression model satisfies the normality assumption.

\subsubsection{Heteroscedasticity Test}

From the figure 6 , there is no discernible structure to this scatterplot chart, which shows the points strewn around the $\mathrm{Y}$ axis, both above and below the zero (0) number. This means that heteroscedasticity is not identified.

\subsubsection{Multicollinearity Test}

From the table 5, the tolerance value obtained from each variable is greater than 0.1 and the VIF value obtained for each variable is smaller than 10. It means that there is no multicollinearity between independent variables.

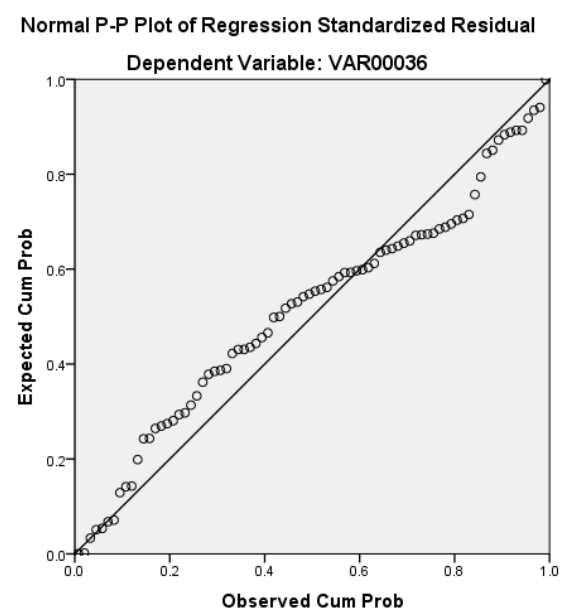

Figure 5 P-P Plot graph for Normality Test

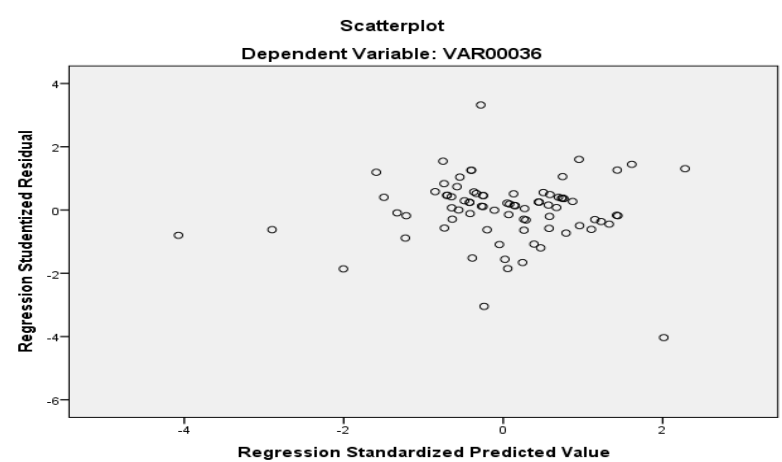

Figure 6 Scatterplot for Heteroscedasticity Test 
Table 5. Result of Multicollinearity Test

\begin{tabular}{|c|r|r|}
\hline \multirow{2}{*}{ Items } & \multicolumn{2}{|c|}{ Collinearity Statistics } \\
\cline { 2 - 3 } & \multicolumn{1}{|c|}{ Tolerance } & \multicolumn{1}{c|}{ VIF } \\
\hline \multirow{2}{*}{ (Constant) } & & \\
\hline Cultural & 0,725 & 1,379 \\
\hline $1 \quad$ Social & 0,728 & 1,374 \\
\hline Personal & 0,675 & 1,481 \\
\hline Psychological & 0,840 & 1,190 \\
\hline
\end{tabular}

a. Dependent Variable: Visiting Intention

\subsection{Multiple Linear Regression}

Multiple Linear regression is carried out to determine the effect of the consumer behavior represented by Cultural Factors, Social Factors, Personal Factors and Psychological Factors on Visiting Intention to shopping centres during the Covid-19 pandemic. Regression is carried out separately each city: Bandung, Solo and Kupang. The test results are as follows:

\section{1) Bandung City}

From the regression table 6, it shows that Cultural, Social and Personal Factors have a positive influence on Visiting Intention to shopping centres and, but viewed from the value of Significance, only Personal Factors that have a value below 0.05, which means Personal Factors have a positive and significant effect on Visiting Intention to shopping centres in Bandung City during the Covid-19 pandemic.

\section{2) Solo City}

From the results (Table 7), it is seen that the four factors have a positive influence on Visiting Intention to shopping centres, but viewed from the value of Significance, only Cultural Factors and Social Factors that have a value below 0.05, which means Cultural Factors and Social Factors have a positive and significant effect on Visiting Intention to shopping centres in Solo city during the Covid-19 pandemic.

\section{3) Kupang City}

From the table 8, Cultural, Personal and Psychological Factors have a positive influence on Visiting Intention to shopping centres, but when viewed from the value of Significance, only Psychological Factors that have a value below 0.05, which means Psychological Factors have a positive and significant effect on Visiting Intention to shopping centres in Kupang city during the Covid-19 pandemic.

Table 6. Result of Multiple Linear Regression for Bandung City

\begin{tabular}{|c|c|c|c|c|c|}
\hline \multirow{2}{*}{ Model } & \multicolumn{2}{|c|}{ Unstandardized Coefficients } & \multirow{2}{*}{$\frac{\text { Standardized Coefficient }}{\text { B }}$} & \multirow{2}{*}{$\mathrm{t}$} & \multirow{2}{*}{ Sig. } \\
\hline & B & Std. Error & & & \\
\hline (Constant) & $-1,414$ & 5,576 & &,- 0254 & 0,803 \\
\hline Cultural & 0,623 & 0,377 & 0,342 & 1,652 & 0,119 \\
\hline 1 Social & 0,178 & 0,400 & 0,093 & 0,445 & 0,662 \\
\hline Personal & 0,905 & 0,388 & 0,531 & 2,332 & 0,034 \\
\hline Psychological & $-0,081$ & 0,209 & $-0,087$ & $-0,387$ & 0,704 \\
\hline
\end{tabular}

a. Dependent Variable: Visiting Intention

Table 7. Result of Multiple Linear Regression for Solo City

\begin{tabular}{|c|c|c|c|c|c|}
\hline \multirow{2}{*}{ Model } & \multicolumn{2}{|c|}{ Unstandardized Coefficients } & \multirow{2}{*}{$\begin{array}{c}\text { Standardized Coefficient } \\
\text { B }\end{array}$} & \multirow{2}{*}{$\mathrm{t}$} & \multirow{2}{*}{ Sig. } \\
\hline & B & Std. Error & & & \\
\hline (Constant) & 1,456 & 2,728 & & 0,534 & 0,599 \\
\hline Cultural & 0,466 & 0,210 & 0,388 & 2,217 & 0,036 \\
\hline 1 Social & 0,535 & 0,204 & 0,401 & 2,627 & 0,015 \\
\hline Personal & 0,124 & 0,191 & 0,129 & 0,651 & 0,521 \\
\hline Psychological & 0,144 & 0,081 & 0,235 & 1,786 & 0,087 \\
\hline
\end{tabular}

a. Dependent Variable: Visiting Intention 
Table 8. Result of Multiple Linear Regression for Kupang City

\begin{tabular}{|c|c|c|c|c|c|}
\hline \multirow{2}{*}{ Model } & \multicolumn{2}{|c|}{ Unstandardized Coefficients } & \multirow{2}{*}{$\frac{\text { Standardized Coefficient }}{\text { B }}$} & \multirow{2}{*}{$\mathrm{t}$} & \multirow{2}{*}{ Sig. } \\
\hline & B & Std. Error & & & \\
\hline (Constant) & 12,180 & 4,750 & & 2,564 & 0,017 \\
\hline Cultural & 0,202 & 0,234 & 0,184 & 0,864 & 0,396 \\
\hline 1 Social & $-0,158$ & 0,261 & $-0,133$ & $-0,604$ & 0,552 \\
\hline Personal & 0,058 & 0,171 & 0,070 & 0,336 & 0,739 \\
\hline Psychological & 0,256 & 0,163 & 0,312 & 1,571 & 0,029 \\
\hline
\end{tabular}

a. Dependent Variable: Visiting Intention

\subsection{Discussion}

From the results of the above study, it can be discussed that there is a slight difference among consumer behavior in the 3 cities. Personal Factors have a positive and significant effect on Visiting Intention to shopping centres in Bandung City during the Covid-19 pandemic. Looking at the questionnaire indicators, the highest score from respondent's answer is the behavior of "visiting this shopping centres because this mall fits with the lifestyle (goods, facilities, restaurant, hangouts, etc.)" and "everything offered by this shopping centres (goods, facilities, places to eat, hangouts, etc.) is as their needs or requirement". This result is supported by their motivation answer (Table 2) that is shopping (2nd highest). From the observations, shopping centres in Bandung provide branded products and franchised restaurants that are full with visitors. The characteristics of mall in Bandung can meet the consumer lifestyle. This is agree with [2] consumer behavior theory which states that lifestyle is an indicator of Personal Factors influences the customer visiting intention to shopping centres.

Meanwhile, different results can be seen from the answers of mall visitors in Solo City, which is the Cultural Factors and Social Factors positively and significantly affect the Visiting Intention to shopping centres in Solo City during the Covid-19 pandemic. The Cultural Factor's indicator "visiting this shopping centres because of geographical proximity" and the indicator "go to this shopping centres because it suits the needs" are the reason why the customers come and visit the mall. Solo customers tend to go to mall because the locations are not too far from where they live and they go shopping as their daily needs. It is also seen in the answer of motivation to the mall is for shopping. Another factor that is also influential is the Social Factor, it can be seen in the indicator "go to shopping centres because they see many people come to it" and "come to this shopping centres because invited by family or want to invite family". From the observation in Solo shopping centres, they were not too crowded at $09.00-15.00 \mathrm{LT}$, but more they were crowded in the afternoon and evening. It means that they go to the shopping centres after working hours or school hours. People who visit the mall feel safer now because the status imposed by the government allows the mall to be opened. Visitors are also seen coming with their families. This is agree with [2] consumer behavior theory which states that Cultural and Social factors influences the customer visiting intention to shopping centres.

The results of respondents' answers in Kupang City are also different from Bandung City and Solo City. Psychological Factors have a positive and significant effect on the Visiting Intention to shopping centres in Kupang City during the Covid-19 pandemic. The indicators of the answers that have the highest value are "go to this shopping centre because they are bored at home or at work", "go to this shopping centre because the Covid-19 case is already at a safer level" and "go to this shopping centre because it has been allowed by the government". From the observation, the visitors were not inside the store but hanging out in the café, and this is supported by the answer of the motivation that they come to meet friends or hang out in the café. This situation happened because the visitors already feel safe from the threat of the Covid-19 and the government allows the operation of shopping centres with safer levels. This behavior is in accordance with [2] theory which states that Psychological Factors influences the customer Visiting Intention to shopping centres.

From the results of the data analysis indicated that Consumer Behavior in Bandung, Solo and Kupang showed different behaviors in visiting shopping centres during Covid-19. This is due to differences in lifestyle, social relationships with family and friends, geographical proximity of shopping centres, goods and facilities provided in malls (shops, restaurants, cafes, etc), safety and rules applied by the government. Ultimately, the highest motivation for people to visit shopping centres during Covid-19 is refreshing and shopping.

\section{CONCLUSION}

From the results of research in three different cities in Indonesia about the comparison of the effect of Consumer Behavior represented by Cultural, Social, Personal and Psychological Factors on Visiting Intention to shopping centres during the Covid-19 pandemic, it was 
concluded that Personal Factors had a positive and significant effect on Visiting Intention to shopping centres in Bandung during the Covid-19 pandemic while in Solo City, Cultural Factors and Social Factors have a positive and significant effect on Visiting Intention to shopping centres during the Covid-19 pandemic and in Kupang City, Psychological Factors have a positive and significant effect on Visiting Intention to shopping centres during the Covid-19 pandemic. This is due to differences in lifestyle, social relationships with family and friends, geographical proximity of shopping centres, goods and facilities provided in malls (shops, restaurants, cafés, etc), safety and rules applied by the government.

\section{REFERENCES}

[1] J. F. Engel, R. D. Blackwell, and P. W. Miniard, "Consumer Behavior, 8th d, Orlando: The Dryden Press," 1995.

[2] P. Kotler and G. Armstrong, Principles of Marketing (Edition 13). 2010.

[3] P. Kotler, Principal of Marketing. Jakarta, 2000.

[4] P. Kotler, "Marketing management/Philip Kotler, Kevin Lane Keller," Pearson Educ. Int., 2012.

[5] J. C. Mowen and M. Minor, Customer Behavior (Chapter 1) 5th Edition. Jakarta: Erlangga, 2001.

[6] N. Setiadi, Cutomer Behavior. Jakarta: Kencana, 2008.

[7] B. Swastha and H. Handoko, Marketing Management (Consumer Behavior Analysis). Jakarta: BPFE UGM, 2000.

[8] Deksono, "Pengaruh Motivasi Wisata dan EWOM Terhadap Minat Berkunjugn Ke Daya Tarik Wisata Goa Pindul," Вестник Росздравнадзора, 2017.

[9] B. Simamora, Guide for Consumer Behavior Research. Surabaya: Pustaka Utama, 2002.

[10] Margono, Research Methodology for Education. Jakarta: Rineka Cipta, 2000.

[11] A. Sudijono, Introduction to Education Statistic. Jakarta: PT. Raja Grafindo Persada, 2009.

[12] Sugiyono, Metode Penelitian Kuantitatif, Kualitatif dan R \& D. Bandung: Alfabeta, 2012.

[13] Sugiyono, Research Methodology, Quantitative Qualitative and R\&B. Bandung: Alfabeta, 2009. 